\title{
Factors associated with exclusive breastfeeding practices in the commune of Sakété, southern Benin: a cross-sectional study
}

\author{
Waliou Amoussa Hounkpatin ${ }^{1 *}$, Sam Bodjrenou ${ }^{1}$, Maryline Baba-Ode ${ }^{1}$, Jaurès Lokonon ${ }^{1}$, Sosthene Vissoh ${ }^{2}$, Célestin \\ Agassounon $^{2}$ and Halimatou Alaofe ${ }^{3}$. \\ ${ }^{1}$ Faculty of Agricultural Sciences of the University of Abomey-Calavi (FSA/UAC), Abomey-Calavi, Benin. \\ ${ }^{2}$ Groupe d'Action pour le Bien Etre Familial NGO (GABF NGO), Pobe, Benin. \\ ${ }^{3}$ Health Promotion Sciences Department, University of Arizona, P.O. Box 245209, 1295 N. Martin Ave., Tucson, AZ 85724, USA. \\ *Corresponding author. E-mail: amouswal@yahoo.fr; Tél: (229) 97052020
}

\begin{abstract}
The purpose of this study was to determine the factors associated with exclusive breastfeeding (EBF) practices in community settings of southern Benin. We conducted a quantitative and qualitative cross-sectional study in Sakété commune. Six midwives and 100 breastfeeding women with at least one child under 6 months of age completed a semi-structured questionnaire. We also conducted focus groups with grandmothers. The quantitative data were analyzed with SPSS 20 using chi-square tests, Student's t-tests, and logistic regression. The data from the focus groups were analyzed thematically. The Information-Education-Communication (IEC) sessions on the EBF were conducted in all the visited maternity care facilities. Nonetheless, only $58 \%$ of breastfeeding mothers followed EBF practices, and most grandmothers did not follow EBF practices. Regression analysis identified that mothers who participated in IEC sessions focused on good infant feeding and nutrition practices and those seeking advice from close relatives were more likely to use EBF. The study revealed a low EBF rate and suggested that interventions could educate mothers and other household members on the importance of timely breastfeeding initiation in the study area.
\end{abstract}

Keywords: Exclusive breastfeeding; Breastfeeding women; Nutritional education; InformationEducation-Communication; Benin 


\section{Introduction}

Maternal and child malnutrition is a significant public health issue globally, but it is especially acute in developing countries, in which it is responsible for $45 \%$ of the deaths of children under $5[1,2]$. It can, however, be prevented in infants and young children based mainly on good feeding practices, such as early initiation of breastfeeding, exclusive breastfeeding (EBF) during the first six months of life, and continued breastfeeding until the age of 24 months, and the introduction of adequate solid/semi-solid foods from six months of age [3]. EBF [4] is of particular significance due to the nutritional and health properties of breast milk, as well as being one of the key factors for determining nutritional status and mother-child bonding [4-11]

According to the World Health Organization (WHO) [12], EBF is the most effective public health intervention to improve child survival. In addition to preventing stunting, compliance with this recommendation can protect children from health problems [13, 14]. By reducing the risk of infection, EBF directly contributes to good growth and optimal nutrient utilization. During the breastfeeding process, antibodies in breast milk reduce the possibility of contamination of the child's body by foreign substances [15]. By not practicing EBF, a child is at risk for allergies, gastroenteritis, and rhinitis, in addition to malnutrition. Furthermore, it contributes to maternal obesity, breast cancer, ovarian cancer, and close births [16]. A cohort study in Ghana, a country in West Africa, found that EBF during the first six months of life could prevent $13 \%$ of deaths among children under five in developing countries [17].

In Africa, only one-third of infants under 6 months are exclusively breastfed [18]. Benin has proven successful in reducing, from $15.6 \%$ in 1996 , to $41.4 \%$ in 2014 and $41.6 \%$ in 2017-2018 [19]. Nevertheless, there are regional disparities. In South Benin, the Plateau department has the lowest rate of newborns who start breastfeeding within one hour of birth $(29.8 \%$ ), and only $18.2 \%$ of children under 6 months are exclusively breastfed. Further, the median duration of EBF within the department is 0.5 months as opposed to 1.8 months at the national level [20]. Thus, the present study aims to identify factors associated with EBF practices in one of the Plateau communes, specifically Sakété. It seeks to identify the factors influencing breastfeeding women regarding EBF in Benin, and more specifically, in Sakété. As a result, the findings of the study could be used to recommend ways to enhance breastfeeding and, subsequently, the nutritional status of infants and young children.

\section{Methodology}

\subsection{Study population}

A cross-sectional study was conducted between August and December 2017 in the commune of Sakété. Study participants included breastfeeding mothers with infants younger than six months and midwives working in public maternity hospitals most frequently frequented by breastfeeding mothers. In addition, we were interested in grandmothers of children under five years of age in the study area, given their influence on the feeding practices adopted by their daughters and daughters-in-law [21].

\subsection{Sampling}

A random sample was taken of those identified as breastfeeding women in the four intervention districts of the Multisectoral Food, Health, and Nutrition Project (PMASN) in Sakété. We determined the sample size using Giezendanner's formula [22] (1).

$$
n=Z^{2} * \frac{p *(1-p)}{i^{2}}
$$

$\mathrm{N}:$ is the sample size

$\mathrm{Z}:$ is the margin coefficient deduced from the confidence rate: 1.96

$\mathrm{p}$ is the prevalence of EBF in the Plateau department. Since this information was not available in the literature (Demographic and Health Surveys) at the time of data collection, we used the national prevalence, i.e., $p=0.414$ [20].

$\mathrm{i}$ is the precision: $10 \%$.

Based on this method, 103 breastfeeding women were sampled at a $10 \%$ wastage rate. The step-by-step sampling method was used for sampling breastfeeding women based on the results of a complete census of the selected four districts. For the second group under study, midwives, an exhaustive sampling was applied. In order to conduct focus group discussions, convenience sampling was used with grandmothers.

\subsection{Ethical Considerations}

As part of the PMASN, the study was conducted to identify solutions for the non-practice of EBF in the commune of Sakété. This project of national interest received the approval of the Ethics Committee under the number (CR $\mathrm{n}^{\circ} 05$ on 26/01/2017 and $\mathrm{N}^{\circ} 15 /$ $\mathrm{MS} / \mathrm{DC} / \mathrm{SGM} / \mathrm{DRFMT/CENRS/SA}$ on 07/04/2017). In addition, breastfeeding women, midwives, and grandmothers granted verbal consent before interviews, and focus groups began.

\subsection{Data Collection}

This study collected both qualitative and quantitative data. A Knowledge, Attitudes, and Practices (KAP) questionnaire was used to perform semi-structured interviews with breastfeeding mothers to assess breastfeeding practices and cultural factors that hinder breastfeeding practice.

We also conducted semi-structured interviews with midwives or nurses in the hospitals and state health centers we visited to ascertain whether information and sensitization sessions were available at health centers concerning EBF. 
The focus group discussions were conducted in Nagot or Goun, depending on the local language spoken by the participants. PMASN field facilitators led the discussions, which were recorded on cell phones with the participants' permission. The collected information was then transcribed before being processed. Focus group discussions focused on the following topics: customs and traditions related to feeding children under 6 months of age, advice given by grandmothers to their daughters or daughters-in-law about feeding their grandchildren under 6 months of age, and grandmothers' perceptions of the EBF.

\subsection{Data processing and analysis}

Data collected during semi-structured interviews were entered using Epi data software and an Excel spreadsheet. The database was then cleaned to eliminate missing and/or incorrect data. Thus, three individuals were excluded from the analyses. The analyses were therefore performed on a sample of $n=100$ mothers. We considered that a child under 6 months of age benefited from the EBF when (i) no liquid (water, herbal tea) was given to him/her during the three days following his/her birth, apart from breast milk, (ii) no liquid, semi-solid or solid food (porridge or other) was given to him/her before the age of 6 months, and (iii) the child took only breast milk the day before the survey.

Data were analyzed using SPSS 20 software. The main statistical analyses performed were the Chi-2 test of independence to assess the relationship between categorical variables and the Student's t-test to compare the means of quantitative variables with a continuous distribution according to the practice or not of EBF. Finally, a logistic multiple regression was performed to identify different factors associated with the practice of EBF.

Data collected during the focus groups were first transcribed and then analyzed by theme.

\section{RESULTS}

The results are presented according to the target groups surveyed.

\subsection{Semi-structured interviews with breastfeeding women}

\subsubsection{Sample Characteristics}

Table 1 presents the socio-economic characteristics of the sample of mothers. Mothers of the children surveyed are mainly Nagot $(42 \%)$, followed by Goun $(38 \%)$. The majority were between the ages of 30-39 (68\%), and half of them were housewives. Petty trade (saleswoman) was the primary source of income for the rest. Their level of education was low; $79 \%$ of them had no education. However, most respondents had given birth at health centers $(90 \%)$ and attended at least one EBF awareness session. Approximately $23 \%$ of the mothers sought advice from a relative on feeding their infants under 6 months of age, and $11 \%$ traveled for a day or more without their infants.

Table 1: Characteristics of the sample of mothers $(n=100)$

Values presented are percentages

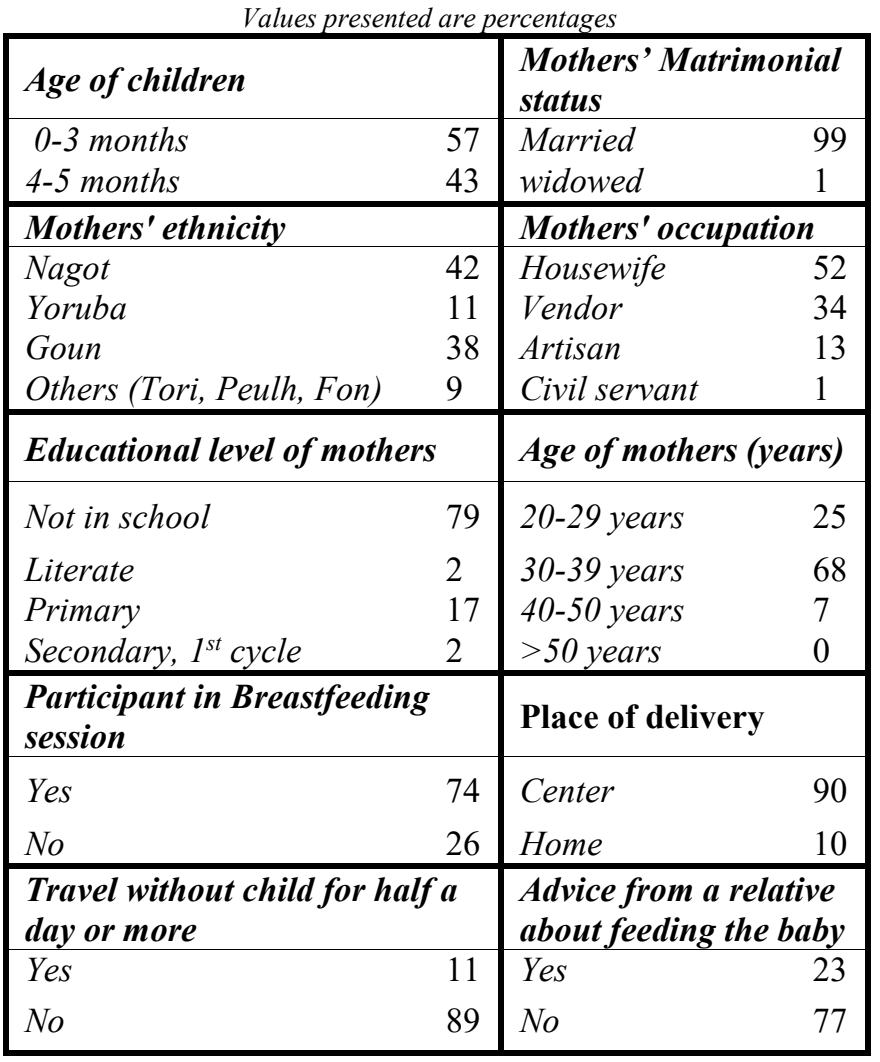

\subsubsection{Breastfeeding practices and associated factors}

About half of all babies (52\%) were breastfed within an hour of their birth. According to mothers' reports, 58\% of children aged 0-5 months were exclusively breastfed.

The factors associated with early initiation were (Table 2): the mother's ethnicity $(\mathrm{p}=0.005)$, her level of education $(p=0.009)$, participation in a sensitization session on $\operatorname{EBF}(p=0.012)$, and the place of delivery $(p=0.033)$. Early breastfeeding was more common in Nagot, Yoruba, and Peulh ethnic groups and uneducated mothers. Finally, breastfeeding rates were higher among pregnant women who delivered in a health center.

Children whose mothers attended EBF awareness sessions $(p=0.001)$ and those who gave birth in health centers $(p=0.010)$ were more likely to receive EBF. Women who practice EBF did not travel without their babies $(p=0.029)$.

Moreover, infants who had been breastfed within an hour of birth were more likely to receive EBF up to 6 months of age $(p=0.018)$ (results not shown).

Table 3 presents the results of the logistic-type linear regression model for the practice of EBF (significant at $\mathrm{p}<0.050$ ). Those mothers who practiced EBF were those who attended nutrition education sessions focused on $\mathrm{EBF}$ and those who seek advice from a relative about how to feed their child. 
Table 2: EBF practice and early initiation by sample characteristics

FTG: Fon, Tori, Goun NYP: Nagot, Yorouba, Peulh IEC: Information-Education-Communication

* The values presented in the table are: means \pm standard deviations for the variables Age of the mother, number of living children, number of children under 5 years and percentage for the other variables.

Depending on the case, the statistical tests performed are: Student's t-test for the means and Chi-square test for the percentages. For the Chi-square test, the statistic is calculated only in cases where some cells contain values less than 5

\begin{tabular}{|c|c|c|c|c|c|c|c|}
\hline \multirow{2}{*}{ Explanatory Variables } & & \multicolumn{3}{|c|}{ Early Initiation } & \multicolumn{3}{|c|}{ EBF practice } \\
\hline & & Yes & No & $\mathrm{p}^{*}$ & Yes & No & $\mathrm{p}$ \\
\hline Age of mother & & $31.42 \pm 4.71$ & $33.5 \pm 4.66$ & 0.250 & $31.8 \pm 4.91$ & $33.3 \pm 4.54$ & 0.138 \\
\hline $\begin{array}{l}\text { Number of children } \\
\text { under } 5 \text { years old }\end{array}$ & & $1,02 \pm 0.139$ & $1.02 \pm 0.144$ & 0.955 & $1.8 \pm 0.451$ & $1.8 \pm 0.470$ & 0.527 \\
\hline \multirow{2}{*}{ Mother's ethnicity } & FTG & 32.7 & 60.4 & \multirow{2}{*}{0.005} & 58.7 & 41.3 & \multirow{2}{*}{0.896} \\
\hline & NYP & 67.3 & 39.6 & & 57.4 & 42.6 & \\
\hline \multirow{2}{*}{ Education level } & Not educated & 71.2 & 91.7 & \multirow{2}{*}{0.009} & 59.3 & 40.7 & \multirow{2}{*}{0.598} \\
\hline & educated & 28.8 & 8.3 & & 52.6 & 47.3 & \\
\hline \multirow{2}{*}{$\begin{array}{l}\text { Possession of a } \\
\text { source of income }\end{array}$} & Yes & 50 & 45.8 & \multirow{2}{*}{0.677} & 56.2 & 43.8 & \multirow{2}{*}{0.733} \\
\hline & No & 50 & 54.2 & & 59.6 & 40.4 & \\
\hline \multirow{2}{*}{$\begin{array}{l}\text { Participation in an } \\
\text { IEC session on EBF }\end{array}$} & Yes & 84.6 & 62.5 & \multirow{2}{*}{0.012} & 74.3 & 25.7 & \multirow{2}{*}{$<0.001$} \\
\hline & No & 15.4 & 37.5 & & 11.5 & 88.5 & \\
\hline \multirow{2}{*}{ Place of delivery } & Household & 3.8 & 16.7 & \multirow{2}{*}{0.033} & 20 & 80 & \multirow{2}{*}{0.010} \\
\hline & Health center & 96.3 & 83.3 & & 62.2 & 37.8 & \\
\hline \multirow{2}{*}{$\begin{array}{l}\text { Taking advice from } \\
\text { someone close to you } \\
\text { about baby feeding }\end{array}$} & Yes & 21.2 & 25 & \multirow{2}{*}{0.648} & 56.5 & 43.5 & \multirow{2}{*}{0.870} \\
\hline & No & 78.8 & 75 & & 58.4 & 41.6 & \\
\hline \multirow{2}{*}{$\begin{array}{l}\text { Travel without the } \\
\text { child for half a day } \\
\text { or more }\end{array}$} & Yes & - & - & \multirow{2}{*}{ - } & 27.3 & 72.7 & \multirow{2}{*}{0.029} \\
\hline & No & - & - & & 61.8 & 38.2 & \\
\hline \multirow{2}{*}{ Perception of EBF } & Positive & - & - & \multirow{2}{*}{ - } & 100 & 2.4 & \multirow{2}{*}{$<0.001$} \\
\hline & Negative & - & - & & 0 & 97.6 & \\
\hline
\end{tabular}

Table 3: Linear regression model for mothers' practice of EBF

\begin{tabular}{lll}
\hline Variables & A & Sig. \\
\hline Age of mother & -0.14 & 0.076 \\
Age of children & 0.06 & 0.824 \\
Sex of children & 0.95 & 0.115 \\
Number of children under 5 & 1.07 & 0.120 \\
Mother's ethnicity & -0.80 & 0.222 \\
Mother's Education level & -0.78 & 0.327 \\
$\begin{array}{l}\text { Possession of a source of } \\
\text { income }\end{array}$ & -0.29 & 0.637 \\
Place of delivery & 1.92 & 0.186 \\
Attendance at a session on & $\mathbf{3 . 6 1}$ & $\mathbf{0 . 0 0 0}$ \\
EBF & & \\
Took advice from a family & $\mathbf{2 . 6 2}$ & $\mathbf{0 . 0 2 5}$ \\
member about feeding the & & \\
child & & \\
Early initiation practice & 0.80 & 0.207 \\
Travel without child at times & 0.31 & 0.835 \\
Constant & -2.49 & 0.377 \\
\hline
\end{tabular}

\subsection{Interviews with midwives}

At all the health centers visited, mothers were educated about the EBF. These training sessions are usually addressed individually to mothers during prenatal and postnatal consultations or in groups during child immunization sessions. These Information-Education-Communication (IEC) sessions provide information that conforms to the $\mathrm{EBF}$ recommendations. In addition to the health centers, some non-governmental organizations (NGOs) are also involved in this awareness-raising effort. Overall, $74 \%$ of respondents reported that they had participated in IEC sessions, mainly through NGOs (54\%) and health agents $(19 \%)$.

\subsection{Focus groups with grandmothers}

Grandmothers play a vital role in the feeding habits of their granddaughters and granddaughters-in-law. The grandmothers act as advisers and guides for the mothers in general. They generally suggest that breast milk be combined with herbal tea, water, and liquid 
porridge from the age of 3 months. Among grandmothers, the practice of EBF is "unsuitable for children," except in Igbola, where the majority said they advise their daughters and sons to practice it.

\section{Discussion}

Among all the mothers surveyed, EBF was practiced by more than half. This rate is relatively higher than previous surveys for Plateau, especially the 2014 Benin Multiple Indicator Cluster Survey [20], which found a rate of $18.2 \%$. This $\mathrm{EBF}$ rate, although insufficient, is satisfactory compared to the national rate and could be explained by the various nutrition programs carried out in the commune by health centers and various NGOs. Participating in IEC sessions on EBF was one factor that positively impacted the mothers' practice of EBF. Another explanation for this result is that one out of two mothers who practiced EBF was a housewife, so she would be more likely to breastfeed her child when the child requests it. Studies conducted in Tunisia [23], Nigeria [24], and Ethiopia [25] have confirmed the positive influence of participation in IEC sessions. A good understanding of the benefits of EBF on the practice and duration of EBF will likely directly affect the nutritional status of children since Reyes et al [13] state that the frequency of participation in programs focused on the well-being of children will improve their nutritional status.

The analysis of binary logistic regression showed that the practice of EBF was positively affected by the opinion of relatives about a child's diet. In Ghana and Kenya, Wanjohi et al [26] and Diji et al [27] found that beliefs and behaviors related to breastfeeding are primarily taught by parents, grandparents, relatives, and companions. It is typical in most African communities for the family to include close relatives. According to Olayemi et al [24], in Nigeria, and Tewabe et al [28] in Ethiopia, very close relatives of the mother are likely to influence the mother's practice of EBF positively. Similarly, Amoussa Hounkpatin et al [29] demonstrate that collaterals, notably grandmothers and mothers-in-law, significantly influence the nutritional practices of infants and young children in Benin. However, they can have positive or negative effects (though usually negatively) on mothers, especially younger ones. Dakpo et al [30] also found that mothers of infants under six months in the commune of Dangbo, located in the same geographic area as the commune of Sakété, our study area, did not practice EBF because of advice from family members. However, in the current study, only $23 \%$ of mothers sought advice from relatives, primarily neighbors and cousins; grandmothers were relatively uninvolved.

Furthermore, the focus group results revealed that solid advocacy in favor of EBF had been carried out in the communities within the framework of various nutrition projects such as the PMASN with religious leaders, village elders (especially grandmothers), groups (artists, tontines, agricultural activities, and others), village leaders and resource persons. Therefore, it is hoped that the change of attitude observed in Igbola village, where grandmothers advise their daughters and sons to practice EBF, will no longer be an exception but gradually spread more widely.

\section{Limitations of the survey}

The data in this study were self-reported by mothers; therefore, there may be some intentional and unintentional biases. In addition, this study was a cross-sectional survey; therefore, only associations can be determined and not causations. Finally, this study was restricted to one geographic region and cannot generalize our results to all breastfeeding mothers in the department or Benin.

\section{Conclusion}

The present study was conducted in the Plateau department and revealed that about half of the children in the commune of Sakété were exclusively breastfed until six months. EBF practice was associated with participation in IEC training sessions and the use of a relative to offer feeding advice. An increase in the effectiveness of community-based nutrition education programs could be achieved by including not only women but also other household members such as fathers, grandmothers, or grandfathers.

\section{References}

1. WHO/OMS, La malnutrition http://www.who.int./medicentre/malnutrition/fr/, consulté en Novembre 2017

2. D.R. Sunuwar, D.R. Singh, P.M.S. Pradhan, Prevalence and factors associated with double and triple burden of malnutrition among mothers and children in Nepal: evidence from 2016 Nepal demographic and health survey. BMC Public Health 20, 405 (2020). https://doi.org/10.1186/s12889-020-8356-y

3. B. Adugna, H. Tadele, F. Reta, Y. Berhan, Determinants of exclusive breastfeeding in infants less than six months of age in Hawassa, an urban setting, Ethiopia. International Breastfeeding Journal, 12, 45, 1-8 (2017).

4. WHO, Global Strategy for Infant and Young Child Feeding. The Optimal Duration of Exclusive breastfeeding. Geneva, Suisse (2001)

5. E.R.J. Giugliani, C.G. Victora, Complementary feeding. Review article. Journal de Pediatria. 0021-7557/00/76-Supl.3/S253 (2000).

6. C. Aarts, Exclusive breastfeeding, does it make a difference? A longitudinal, prospective study of 
daily feeding practices, health and growth in a sample of Swedish infants. Acta Universitatis Upsaliensis. Comprehensive Summaries of Uppsala Dissertations from the Faculty of Medicine 1016, 59 pp. Uppsala. ISBN 91-5544984-0 (2001)

7. WHO/OMS, UNICEF, Stratégie mondiale pour l'alimentation du nourrisson et du jeune enfant. Genève, Suisse (2003)

8. G. Jones, R.W. Steketee, R.E. Black, Z.A. Bhutta, S.S. Morris, How many child deaths can we prevent this year? Lancet 62, 65-71 (2003), http://dx.doi.org/10.1016/S01406736 (03)13811-1

9. B.L. Horta, R. Bahl, J.C. Martines, C.G. Victora, Evidence on the long-term effects of breastfeeding: Systematic reviews and meta-analyses. WHO Library Cataloguing-in-Publication Data (2007)

10. V.G.N. Simon, J.M. Pacheco de Souza, S. Buongermino de Souza, Breastfeeding, complementary feeding, overweight and obesity in pre-school children. Rev Saú de Pública 43, 1 (2008)

11. B.L.K. Dhammika, M.S. Gunawardena, Knowledge, practices and concerns regarding exclusive breastfeeding for six months among mothers of infants in a suburban setting in Sri Lanka. Sri Lanka Journal of Child Health 41, 1, 914 (2012)

12. WHO, Breastfeeding: Overview. https://www.who.int/health-

topics/breastfeeding\#tab=tab_1. Consulté le 14/06/2021

13. H. Reyes, R. Pérez-Cuevas, A. Sandoval, R. Castillo, J.I. Santos, S.V. Doubova, G. Gutiérrez, The family as a determinant of stunting in children living in conditions of extreme poverty: a casecontrol study. BMC Public Health 4, 57 (2004)

14. R. Paudel, B. Pradhan, R.R. Wagle, D.P. Pahari, S.R. Onta, Risk Factors for Stunting Among Children: A Community Based Case Control Study in N Nepal. Kathmandu Univ Med J. 39, 3, 18-24 (2012)

15. R.K. Ayisi, A.B. Wakoli, Exclusive breastfeeding practice: its implication on nutrition status, growth and morbidity pattern among infants aged 0-6 months. Global Journal of Biology, Agriculture and Health Sciences 3, 1, 254-258 (2014)

16. O. Mariko, Etude sur les connaissances, attitudes et pratiques des femmes sur l'allaitement maternel exclusif dans le quartier de sogoniko en commune vi du district de bamako. Mémoire de Doctorat en Médecine (Diplôme d'Etat). Faculté de Médecine, de Pharmacie et d'Odonto-Stomatologie, Université de Bamako, Bamako, Mali, p119 (2010).

17. G. Jones, R.W. Steketee, R.E. Black, Z.A. Bhutta, S.S. Morris, Group BCSS. How many child deaths can we prevent this year? The Lancet 362, 65-71 (2003). doi: 10.1016/S0140-6736(03)13811-1
18. GBD 2017 Risk Factor Collaborators. Global, regional, and national comparative risk assessment of 84 behavioural, environmental and occupational, and metabolic risks or clusters of risks for 195 countries and territories, 1990-2017: a systematic analysis for the Global Burden of Disease Study 2017. The Lancet, 392, 10159, 1923-1994, ISSN 0140-6736 (2018) https://doi.org/10.1016/S0140-6736(18)32225-6.v

19. Institut National de la Statistique et de l'Analyse Économique (INSAE), ICF, Enquête Démographique et de Santé au Bénin, 2017-2018. INSAE et ICF : Cotonou, Bénin et Rockville, Maryland, USA (2019)

20. Institut National de la Statistique et de l'Analyse Economique (INSAE), Enquête par grappes à indicateurs multiples (MICS). Institut National de la Statistique et de l'Analyse Economique, Cotonou, Bénin (2015)

21. J. Aubel, The role and influence of grandmothers on childnutrition: culturally designated advisors and caregivers. Maternal and Child Nutrition, 8, 19-35 (2012)

22. F. Giezendanner, Taille d'un échantillon aléatoire et marge d'erreur (2012) Taille d'un échantillon aléatoire et Marge d'erreur - CMS-SPIP (icietlage.ch)

23. B. Slama, I. Ayari, F. Ouzini, O. Belhadj, N. Achour, Allaitement maternel exclusif et allaitement mixte : connaissances, attitudes et pratiques des mères primipares. La Revue de Santé de la Méditerranée orientale, 16, 6, 630-635 (2010).

24. O.D. Olayemi, A.O. Williams, O. Adekugbe, M.O. Odubanjo, O. Fayehun, J. Uneke, W. Ogala, O. Omotade, Factors influencing the practice of exclusive breastfeeding in three regions of Nigeria. Journal of Community Medicine and Primary Health Care 26, 1, 30-43, (2014)

25. A. Lenja, D. Tsegaye, Y. Bereket, Y. Mulugeta, Determinants of exclusive breastfeedingpractice to infants aged less than sixmonths in Offa district, Southern Ethiopia: across-sectional study. International Breastfeeding Journal 11, 32 (2016) DOI 10.1186/s13006-016-0091-8

26. M. Wanjohi, P. Griffiths, F. Wekesah, P. Muriuki, N. Muhia, R.N. Musoke, H. Fouts, N.J. Madise, E.W. Kimani-Murage. Sociocultural factors influencing breastfeeding practices in two slums in Nairobi, Kenya. International Breastfeeding Journal 12, 5, 1-8 (2017)

27. A.K.A. Diji, V. Bam, E. Asante, A. Lomotey, S. Yeboah, H.A. Owusu, Challenges and predictors of exclusive breastfeeding among mothers attending the child welfare clinic at a regional hospital in Ghana: a descriptive crosssectional study. International Breastfeeding Journal 12, 13, 1-7 (2017)

28. T. Tewabe, A. Mandesh, T. Gualu, G. Alem, G. Mekuria, H. Zeleke, Exclusive breastfeeding 
practice and associated factors among mothers in Motta town, East Gojjam zone, Amhara Regional State, Ethiopia, 2015: a cross-sectional study. International Breastfeeding Journal 12, 12, 1-7 (2017)

29. W. Amoussa Hounkpatin, S. Blum, A. Le Dain, A, Badou Savi, Etude des déterminants des pratiques d'alimentation complémentaire des enfants de moins de 2 ans; Cas de 3 localités au Bénin: Boukoumbé, Djakotomey et Kétou. UNICEF, Cotono, Bénin, (2014)

30. P.C. Dakpo, F. Messan, S.A. Nakou, D.A. Mikode, S.R. Lodonou. Contribution de l'allaitement maternel exclusif à la santé communautaire en Afrique subsaharienne: Cas de la commune de Dangbo au Bénin. (2013) Available from: https://www.researchgate.net/publication/273319 958_Contribution_de_1\%27allaitement_maternel_ exclusif_a_la_sante_communautaire_en_Afrique _subsaharienne_cas_de_la_commune_de_Dangb o_au_Benin\#fullTextFileContent [accessed Jun 14 $2021]$. 